\title{
Evolution of the Unsaturated Zone Testing at Yucca Mountain
}

\author{
J.S.Y. Wang* and G.S. Bodvarsson \\ Earth Sciences Division, Lawrence Berkeley National Laboratory, MS 90-1116, One \\ Cyclotron Road, Berkeley, CA 94720, USA \\ * Corresponding author. FAX + 1-510-486-6115; E-mail: jiswang@lbl.gov
}

\begin{abstract}
The evaluation of the Yucca Mountain site has evolved from intensive surfacebased investigations in the early 1980 s to current focus on testing in underground drifts. Different periods of site-characterization activities and prominent issues concerning the unsaturated zone are summarized. Data-collection activities have evolved from mapping of faults and fractures, to estimation of percolation through tuff layers, and to quantification of seepage into drifts. Evaluation of discrete flow paths in drifts has led to fracture-matrix interaction and matrix diffusion tests over different scales. The effects of tuff interfaces and local faults are evaluated in fractured-welded and porous-nonwelded units. Mobilization of matrix water and redistribution of moisture are measured in thermal tests. Lessons learned from underground tests are used to focus on processes needed for additional quantification. Migration through the drift shadow zone and liquid flow through faults are two important issues that have evolved from current knowledge.
\end{abstract}

Key Words: Seepage, Fracture Flow, Fracture-Matrix Interaction, Matrix Diffusion, Percolation, Flow and Transport, Unsaturated Zone, Yucca Mountain.

\section{Unsaturated Zone Characterization}

As the potential site for a nuclear waste repository, Yucca Mountain, Nevada is considered to have the following favorable hydrogeological characteristics: (1) a desert 
setting with arid climate, and (2) a deep water table below a thick unsaturated zone (UZ). In a desert environment, the total amount of available water is small. Even less water is expected to seep into underground drifts in the UZ.

The concept of emplacing nuclear waste in the UZ within an arid region was first proposed by the U.S. Geological Survey (USGS) (Winograd, 1981). The U.S. Department of Energy (DOE) selected Yucca Mountain for detailed study and initiated site investigations in the early 1980s. A Site Characterization Plan (SCP) was completed in 1988 for systematic surface-based investigations, underground testing, laboratory studies, and modeling activities (DOE, 1988). Figure 1 includes the main deep boreholes at Yucca Mountain, together with the underground Exploratory Studies Facility (ESF) loop and the Cross Drift. Yucca Mountain is a flat-topped ridge rising approximately $300 \mathrm{~m}$ above the adjacent valleys. The potential repository block is located between the ESF Main Drift and the Solitario Canyon to the west.

\subsection{Chronology of Site Characterization}

Chronology of the UZ site characterization effort is summarized in Figure 2. The characterization activities may be grouped into four distinct periods: (1) the early 1980s, (2) the period from 1986 to 1991 , (3) the early 1990s, and (4) the current period (mid1990s to the present).

During the first period, the drilling of boreholes from the land surface was the main focus. Most of the early deep boreholes were drilled away from the potential repository block along nearby washes; they include the geological $(\mathrm{G})$, hydrological $(\mathrm{H})$, water table (WT), and UZ series of boreholes. These boreholes were used to define the 
stratigraphy, locate the water table, collect cores, and test in-situ borehole monitoring techniques.

These early studies lead to a conceptual model for Yucca Mountain site involving flow and transport through alternating welded and nonwelded tuff layers, intersected by major faults (Montazer and Wilson, 1984). The main tuff units in the UZ at Yucca Mountain are the Tiva Canyon welded hydrogeologic unit (TCw), the Paintbrush nonwelded hydrogeologic unit (PTn), the Topopah Spring welded hydrogeologic unit (TSw), and the Calico Hills nonwelded hydrogeologic unit (CHn, with vitric: $\mathrm{CHnv}$, and zeolitic: CHnz). Matrix properties of core samples have been used to define hydrogeological units (Flint, 1998). The matrix of the PTn and CHnv units has sufficiently high permeabilities to accommodate the percolation, while the $\mathrm{TCw}, \mathrm{TSw}$, and $\mathrm{CHnz}$ units have low matrix permeabilities that necessitate significant flow through fractures.

The second period, from 1986 to 1991, was devoted to the development of characterization plans, including the formulation of quality assurance programs. Nearsurface monitoring and intensive laboratory measurements of flow and transport parameters were conducted. The design of the original shaft access for the ESF in the SCP was revised to allow ramp access. (With the underlying tuff layers gently tilted to the east, the middle of the UZ can be accessed by nearly horizontal ramps from the base of the eastern slope.) During this period, discrete and continuum models for fractured media were explored. The heat transfer and thermal-hydrological (TH) modeling methodologies were also established (e.g., Pruess et al., 1990a, b).

The third period, in the early 1990s, launched the specific design, preparation, and excavation of the ESF for underground access to the tuff units. Borehole drilling was 
resumed over the block for UZ investigations and along the North Ramp of the ESF (the NRG series) for design and geotechnical evaluations. Collections of samples for hydrological and geochemical characterization (especially for ${ }^{36} \mathrm{Cl}$ and calcite studies) were intensified, and networks of boreholes were instrumented for pneumatic and moisture monitoring. During this period, the integration of site data into models was initiated, and the basic probabilistic approach for total system performance assessment (TSPA) was improved.

During the current period, the mid-1990s to the present, excavation of the main loop of the ESF and the Cross Drift was completed, alcoves and niches excavated, and boreholes drilled (the SD series) for enhanced characterization of the repository block (ECRB). From 1994 to 1997, the approximately $8 \mathrm{~km}$ long, $8 \mathrm{~m}$ diameter ESF main loop was excavated with a Tunnel Boring Machine (TBM). The $2.7 \mathrm{~km}$ long, $5 \mathrm{~m}$ diameter Cross Drift was excavated with a smaller TBM in 1997 and 1998. The Busted Butte site was excavated in 1997 for UZ transport testing in the CHnv.

The ESF ramps penetrate TCw, PTn, and the upper lithophysal zone of TSw. Four alcoves were excavated along the North Ramp in the upper $\mathrm{TCw}$ unit (Alcove 1), at the Bow Ridge fault (Alcove 2), at the upper PTn contact (Alcove 3), and at the lower PTn contact (Alcove 4). The Main Drift is at the depth of the potential repository, with most of it located in the middle nonlithophysal zone of TSw. Along the ESF Main Drift, Alcove 5 was excavated for thermal tests, and Alcoves 6 and 7 were excavated for characterization of the Ghost Dance fault. Four niches (Niches 3566, 3650, 3107, and 4788 - niches are short drifts, typically $10 \mathrm{~m}$ long) were excavated for in-situ seepage testing and monitoring. 
The Cross Drift provides underground access to the lower lithophysal and lower nonlithophysal zones of TSw, and to the Solitario Canyon fault. According to the current design, approximately $10 \%$ of the potential repository area is located in the middle nonlithophysal zone, $78 \%$ in the lower lithophysal zone, and $12 \%$ in the lower nonlithophysal zone of TSw. In 2000, Cross Drift Niche 1620 was excavated in the lower lithophysal zone of TSw, and Alcove 8 was excavated in the Cross Drift directly above Niche 3107 in the ESF Main Drift at the crossover point. The Cross Drift terminates beyond the western block boundary, in the area where the PTn is absent and the upper lithophysal zone of TSw is exposed on the steep outcrop below the crest on the Solitario Canyon wall (Bodvarsson et al. 2000, Section 2.1).

This paper focuses on the field-testing activities in boreholes and underground drifts. Results of laboratory data-collection activities on core and fluid samples, together with detailed description of the evolution of modeling activities, are documented in Bodvarsson et al. (2000). Laboratory and field data are used for the calibration, validation, and integration of UZ process models. During the current period, the integration of process models and performance models has been intensified. Direct inputs have been provided from the UZ flow and transport model to the TSPA.

\subsection{Prominent Issues for the $U Z$}

The basic issues of limited water flow to the potential repository horizon and retarded radionuclide transport through the UZ were formulated in the early 1980 s and have now been investigated for over two decades. In the course of site characterization for this system, new concepts and hypotheses have been developed and controversial issues have been evaluated and resolved (or uncertainties addressed). The topics of focus within 
the site characterization program evolved dynamically, especially in the early period before the SCP. The sensational topics in the 1980s included the origins of near-surface caliches (carbonate deposits), the possibility of water table rise under conditions of wet climates and seismic events, and the potential benefits of a hot potential repository - with high temperatures induced by concentrated waste-loading. The prominent topics in the 1990s included the detection of bomb-pulse signals from ${ }^{36} \mathrm{Cl}$ measurements in borehole and ESF samples, the estimation of higher percolation fluxes than previously modeled, and the field observation of a seepage threshold that may limit water flux into drifts. These influential issues had significant impacts on the focus of data collection activities.

\section{Evolution of Fault and Fracture Mapping and Fracture Filling Characterization}

Faults and fractures are potential flow paths. Mapping identifies these features while fracture fillings may indicate existence of flow over geological time scales. Extensive geological and geochemical characterization has been conducted.

\subsection{Fault and Fracture Mapping}

The site characterization started with geological mapping of faults on the land surface. The map of Yucca Mountain by Scott and Bonk (1984) was updated and refined by Day et al. (1998) to include additional small faults on the surface (e.g., the Sundance fault). The bedrock of Yucca Mountain in fractured TCw is incised by a series of stream channels. In the north, the ridge is cut by northwest-to-southeast trending washes associated with faults.

Detailed line surveys and full peripheral mapping of fracture networks were conducted along the ESF drifts directly following the TBM excavation in the 1990s. New 
features were mapped, including the observations of an intensely fractured zone in the southern part of the ESF Main Drift (Buesch and Spengler, 1998), and several new faults in the western part of the Cross Drift with relatively small offsets (Bodvarsson et al., 2000, Appendix I). Seismic imaging between land surface and along the ESF Main Drift was used to map fractured zones (Majer et al., 1998). Figure 3 illustrates the geologic mapping and geophysical studies conducted on the land surface and in the ESF.

\subsection{Fracture Filling Characterization}

Near-surface caliches extend to shallow depths as fracture fillings. Evidence from surface trench studies indicates that the caliche deposits are related to dissolution of carbonate minerals by rainwater and re-precipitation as a result of evapotranspiration. The speculation that caliche formed by seismic pumping of water from depths below the water table has not been substantiated (Stuckless et al., 1991). Extensive calcite and secondary mineral evaluations also have been conducted in the 1990s for samples collected along the ESF for examining the alternation of flow paths, averaged over millions of years (Paces et al., 1998; Fabryka-Martin, 2000, Section 6.5).

\section{Evolution of Site-Scale Hydrological Characterization}

Water enters the surface (infiltration) and redistributes throughout the UZ (percolation) in tuff layers and to the faults, as summarized in the following sections.

\subsection{Climate and Infiltration}

Modern climate data have been collected in and around the Yucca Mountain site since 1988. The climate studies have also evaluated long-term records of analog sites to project future climates (Forester, 2000). Nearly $95 \%$ of the $170 \mathrm{~mm} / \mathrm{yr}$ precipitation over 
the site is either runs off or is lost to evaporation (Hevesi et al., 1994). The infiltration studies at Yucca Mountain were conducted between 1984 and 1995 and used nearly 100 shallow boreholes across washes and on the crest to measure (weekly or monthly) the changes in water-content profiles in response to precipitation and snow-melt events (Flint and Flint, 1995). Most of the surface deposits in washes and valleys are alluvium. Waterbalance calculations from precipitation, evapotranspiration, run-on, and run-off along washes are used to derive the net infiltration flux distribution over the ridge top, side slopes, and stream channels. Areas with exposed bedrock and no soil cover have a higher infiltration flux compared to areas with soil covers that have substantial storage capacity for excess water.

\subsection{Deep Borehole Measurements}

Surface-based borehole measurements in the early 1980s included the instrumentation of UZ-1 in the Drill Hole Wash (Montazer, 1987) and pneumatic monitoring in UZ-6 and UZ-6a on the crest near the Solitario Canyon cliff (Weeks, 1987). Eight deep boreholes were instrumented in the 1990s for extensive testing and monitoring of barometric pressure, moisture potential, and temperature in sealed borehole intervals (Rousseau et al., 1999). The pneumatic data (damping and lag of barometric signals) were used to derive effective parameters for the PTn and TSw units and properties of the Ghost Dance fault and other faults (Ahlers et al., 1999). Air permeability was measured along four surface-based boreholes with straddle packers (LeCain, 1997).

\subsection{Percolation Estimates}

Redistribution of percolation and determination of the fracture flow component have been estimated by the UZ model. Early estimates of percolation flux were based on 
the assumption of matrix-dominated flow calibrated by saturation profile data alone. Subsequent investigations have shown that the welded tuff matrix has low permeability and therefore the matrix flow is a small fraction of percolation flux in the $\mathrm{TCw}$ and $\mathrm{TSw}$ (Wu et al., 1999; Bodvarsson et al., 2000, Sections 3.6 and 3.7).

Currently, the estimate of percolation flux ranges from 1 to $10 \mathrm{~mm} / \mathrm{yr}$. These values result from the inclusion of temperature, age-dating, and geochemical data together with pneumatic and hydrological data. The additional field data that indicate higher values of percolation flux include the prevailing low geothermal gradient associated with convective heat transfer, the relatively young water found at depth, and the low concentration of dissolved salts in pore water and in perched-water bodies. For the present-day climate, the majority of percolation flux at the potential repository level in TSw is fracture flow ( $\sim 84 \%$, Bodvarsson et al., 2000, Section 3.7). An active fracture model (Liu et al., 1998) has been used for the fracture-matrix interaction. Over the site, a significant fraction of the flow is diverted by tilted layers (mainly through nonwelded units) to the faults (from $\sim 4 \%$ at the surface, to $\sim 15 \%$ below the PTn in TSw, and to $\sim$ 35\% below the CHn at the water table, Bodvarsson et al., 2000, Section 3.7).

\section{Evolution of Drift-Scale Seepage and Fracture-Matrix Tests in Welded Tuff}

A fraction of the percolation flux may enter the potential waste emplacement drifts. To quantify seepage into drifts, fracture-matrix interactions, and matrix diffusion, tests have been conducted at several welded tuff sites in the ESF.

\subsection{Characterization of Fracture Heterogeneity at Test Sites}


Air-injection tests with multiple packers have been conducted from 1996 to present at all hydrological test sites in the ESF to measure air permeability and to characterize formation heterogeneity. With fast responses and a benign impact on the rock mass, airinjection tests are an effective method for site characterization (Cook, 2000). Airpermeability profiles were used for selecting liquid test intervals. Repeated air-injection tests were conducted before and after niche excavation to quantify the excavation-induced permeability changes (Wang and Elsworth, 1999).

\subsection{Observation of Liquid Flow Paths}

In the dry excavation of Niche 3566 in the vicinity of the Sundance fault, a damp feature was observed in 1997, as illustrated in Figure 4 (Wang et al., 1999). The nearly vertical feature, $0.3 \mathrm{~m}$ wide by over $3 \mathrm{~m}$ long, dried up before a bulkhead could be installed (to seal the niche space and to minimize evaporation induced by ventilation). The full rewetting of this feature was not observed after over two years of bulkhead closure at this niche site. Figure 4 also illustrates that the Sundance fault is one of several faults and features with bomb-pulse signals detected by ${ }^{36} \mathrm{Cl} / \mathrm{Cl}$ measurements along the ESF (Fabryka-Martin, 2000, Section 6.6). No other damp features of the same nature have been observed so far at other sites in the ESF.

To further characterize potential flow paths, artificial liquid release tests were conducted. Prior to all niche excavations, finite volumes of water ( 1 liter $)$ traced with dyes were released into selected borehole intervals (each of $0.3 \mathrm{~m}$ length to simulate a discrete flow path). During excavation, the dyed liquid flow paths were observed to characterize flow paths along fractures. For the first four niches in the middle nonlithophysal zone of TSw, the flow paths were mostly vertically oriented, indicating 
that flow within fractures was influenced strongly by gravity and weakly by capillary forces (Wang et al., 1999). In observations at Cross Drift Niche 1620 in the lower lithophysal zone of TSw, some symmetric patterns were observed around release borehole intervals, as illustrated in Figure 5, indicating that the effective capillarity is stronger than the corresponding strength in the middle nonlithophysal zone. However, the average airpermeability in the lower lithophysal site is higher than values in the middle nonlithophysal sites. In lithophysal tuff, the cavities are likely connected by large fractures to contribute to the large permeability, while small fractures are likely to contribute to the strong capillarity observed.

\subsection{Rationale for Evaluation of Seepage}

No continuous dripping (or seepage) was observed during ESF excavation. The capillary barrier mechanism (Philip et al., 1989) may explain the lack of seepage in UZ underground drifts. Under unsaturated conditions, capillary forces can hold water within the rock mass.

Ventilation, needed for underground operations and construction activities, may also explain the lack of observed seepage. Ventilation can remove a large amount of moisture, dry the rock behind the drift walls, and suppress seepage.

\subsection{Passive Seepage Monitoring}

To determine if seepage returns if there is no ventilation, two drift-sealing studies are now ongoing. The first study is at Alcove 7 in an over $100 \mathrm{~m}$ long segment intersecting the Ghost Dance fault. The second study is in the last one-third of the Cross Drift, a $1,000 \mathrm{~m}$ scale segment that intersects the Solitario Canyon fault. Both sealing 
studies deploy multiple bulkheads for better isolation from ventilation. Heat-dissipation probes and psychrometers in boreholes are currently used to monitor water potential along the drifts and in the rock. Relative humidity sensors monitor the effects of ventilation on moisture conditions, while neutron logging is used to measure saturation changes associated with drying. Available data indicate that the ventilation-induced effects may have penetrated the rock greater than $3 \mathrm{~m}$ and the rewetting processes in the rock matrix may take several years behind bulkheads. The fractures may rewet over shorter time frame if percolation above the dry zone is sufficiently high to supply water, penetrate the dry zone, and reach the drift wall.

\subsection{Niche Seepage Tests}

Seepage tests, from 1998 to the present, involve the release of liquid water above the niche ceiling and the collection of seeps into the niche if they occur. Niche seepage tests have been designed to evaluate the capillary-barrier mechanism and to quantify seepage and seepage threshold. Aqueous dye tracers were released as pulses above the niche ceiling to represent episodic percolation events, as illustrated in Figure 6 for seepage tests at Niche 3650 (with the distance of $\sim 0.65 \mathrm{~m}$ between release point and niche ceiling). Tracers used in the seepage tests are sampled to evaluate the spatial distribution of flow paths. Seepage flow paths indicated by the presence of dyes on the niche ceilings are associated with transient wetting-front movement through fractures.

The seepage threshold for releases at a given borehole interval is determined by a series of tests, in which flow rates are decreased until no seeps occur. The wetting-front arrival at the niche ceiling is determined by visual or video observations. The seepage 
threshold data and the wetting-front movement data are used to derive fracture characteristic curves for in-situ conditions.

The first series of seepage tests at Niche 3650 in 1997 and 1998 were conducted by releasing finite amounts of water (on the order of liters) to confirm the presence of a capillary barrier and the seepage threshold concept (Wang et al., 1999, Trautz and Wang, 2001). To address the need of near steady-state data for better quantification of seepage rate, later tests were conducted with steady rate of release over long durations for each test (nominally requiring hundreds of liters).

The concept of constructing niches along the ESF Main Drift was originally motivated in 1997 by the need to isolate a drift-size opening with a bulkhead from the ventilation in the Main Drift. To minimize the effects of ventilation in suppressing seepage, drift seepage tests at Niche 3107, at Niche 4788 in the intensely fractured zone, and at Cross Drift Niche 1620 in the lower lithophysal zone of TSw were conducted behind bulkheads and under high humidity conditions. The effects of ventilation on seepage and spatial heterogeneity on pneumatic and seepage characteristics are also being evaluated systematically (at regularly spaced intervals) along the Cross Drift, using slanted boreholes drilled into the drift ceiling.

Seepage modeling results (based on parameters calibrated against available seepage test data) to date indicate that the seepage threshold is on the order of $200 \mathrm{~mm} / \mathrm{yr}$ or more for the middle nonlithophysal zone of TSw. For the lower lithophysal zone, the seepage threshold could be one order of magnitude higher (Li and Tsang, 2000, Figure 5 and Tables 5 through 8; Finsterle et al., this issue). Since the percolating water above the 
drift area ranges from 1 to $10 \mathrm{~mm} / \mathrm{yr}$ under present-day climate (Section 3.3), no seepage is expected.

\subsection{Fracture-Matrix Interaction Test}

Observations of fracture flow paths and seepage processes above niches motivated additional tests in fractured welded tuff in 1998 to evaluate the contribution of rock matrix to overall flow and tracer transport. If the contact time between fracture water and unsaturated matrix is long, water can imbibe into the matrix. While niche seepage data for episodic flow conditions have been adequately analyzed with fracture parameters alone (Birkholzer et al., 1999; Wang et al., 1999; Finsterle et al., this issue), analysis of tests of long duration requires the quantification of fracture-matrix interaction.

The dominance of fracture flow and the dependence of flow on injection rate were evaluated in a test bed at Alcove 6, as illustrated in Figure 7. The slot below the test bed was used to collect the fast-fracture-flow component. The amount of water imbibed into the welded tuff matrix was estimated from mass balance of the water injected and collected. A series of tests were conducted over time periods longer than the episodic releases in niche tests, and with larger volumes of traced water. Fracture flow fractions ranged from $60 \%$ to $80 \%$ for this test bed in the middle nonlithophysal zone of TSw (Salve et al., 2002). Tracers were shown to migrate into and out of the welded matrix in test series (Hu et al., 2001).

\subsection{Large-Scale Infiltration and Seepage Tests at Alcove 1}

To simulate large infiltration events associated with El Niño conditions of high precipitation and to evaluate matrix effects over long flow paths, a large-scale infiltration 
and seepage test was conducted in Alcove 1, from 1998 to 2000, near the North Portal (see Figure 8). In this test, a drip irrigation system on the outcrop $\sim 30 \mathrm{~m}$ directly above Alcove 1 was used. At this location in fractured $\mathrm{TCw}$, the first seepage took nearly two months (57 days) to appear in the alcove. The test results show that matrix diffusion is important in diluting the tracer concentration over long flow paths (Liu et al., this issue).

\subsection{Large-Scale Matrix Diffusion Test between Alcove 8 and Niche 3107}

The testing approach and control have been improved and applied to another underground location in the TSw. This is the unique location where the Cross Drift crosses over the ESF Main Drift. During the excavation of the Cross Drift in 1998, the migration of construction water was monitored $\sim 20 \mathrm{~m}$ below. No seepage was observed when the TBM passed over the Main Drift.

At the crossover location, Alcove 8 in the Cross Drift is now used for controlled liquid releases and Niche 3107 (directly below) has been instrumented for seepage detection. The test bed includes the interface between upper lithophysal and middle nonlithophysal zones of TSw. The first series of tests focuses on flow and transport through a local fault discovered at Alcove 8 during excavation. Preliminary results indicate that flow movement along a small fault is qualitatively similar to the observation at Alcove 1, with first seepage appearing over one month (35 days) after start of infiltration.

\section{Evolution of Flow and Transport in Nonwelded Tuff}


While fracture flow is the dominant percolation component in welded tuff, matrix flow is much more important in nonwelded tuff, both in PTn above, and in CHn below the potential repository horizon. Two tests have been conducted in these tuff units.

\subsection{Paintbrush Tuff Fault Test in Alcove 4}

Figure 9 illustrates that the Alcove 4 test bed in the PTn within the ESF includes a small fault and PTn layers. In contrast to TSw, the PTn has a large capacity to absorb water and to dampen flow pulses along the fault. The water intake rate declined with time. One hypothesis to explain the slow decline is the possible swelling of a PTn argillic layer and subsequent reduction of fault permeability (Salve and Oldenburg, 2001). An alternative analysis with nonlinear dynamics suggests that entrapped air may contribute to the flow rate variations (Faybishenko et al., this issue). These findings help determine the behavior of flow through the PTn.

\subsection{Calico Hills Transport Tests at Busted Butte}

Retardation can reduce concentrations of radionuclides along flow paths. Transport processes through the $\mathrm{CHnv}$ unit are currently under investigation at the Busted Butte underground facility. This facility consists of a drift complex excavated $70 \mathrm{~m}$ below the land surface. From 1998 to 2001, tracer-injection tests, sorbing pad collection in monitoring boreholes, geophysical imaging measurements, and partial mine-out have been performed. The available data and model analyses of the ongoing tests are documented in Conca (2000, Section 6.8) and Tseng et al. (this issue). Examples of plume configuration and ground penetrating radar images are illustrated in Figure 10. 
Phase 1A test results indicated that the transport through the $\mathrm{CHnv}$ unit is dominated by capillary-driven flow, with a well-defined plume developed following tracer injection. The Busted Butte test block contains the interface between TSw basal vitrophyre and CHnv. The transport tests in Phase 1B and Phase 2 include both injections into the TSw basal vitrophyre and injections and collections in the CHnv below the interface. The available results confirm that transport through the fractured vitrophyre unit (with a local fault inferred in the Phase 2 block) is heterogeneous.

\section{Evolution of Thermal Testing}

Water in the matrix can be mobilized by heating. If boiling occurs, the vapor can migrate from the tuff matrix to fractures and transport to cooler regions distant from the heat source. Since nuclear waste releases heat due to radioactive decay, heater tests are important for potential repository studies. In late 1980s and early 1990s, the possibility of using a high heat load to keep liquid away from waste packages was extensively modeled (Buscheck and Nitao, 1993). In more recent years, the ventilation is being considered as an important component to remove heat during the thermal periods. Two underground thermal tests have been conducted to evaluate coupled processes in the rock around a single heater and around a full-scale drift. The tests are located at Alcove 5 at the north end of the ESF Main Drift, near the top of the middle nonlithophysal zone of the TSw unit.

\subsection{Single Heater Test}

The Single Heater Test (SHT) was conducted over 9 months in 1996-1997 to evaluate the thermal-hydrological-chemical-mechanical (THCM) coupled processes in fractured tuff, as illustrated in Figure 11. Drainage of condensate to the region below the 
heater was observed. Condensate induced by heating was transported in the fractures and collected in packed borehole intervals. Crosshole air-permeability tests and geophysical tomography were used to detect the changes in rock moisture content in the test block. Measurements showed that the dry-out zone extended about $1 \mathrm{~m}$ from the heater hole and that the condensate zone below the heater horizon was larger than that above the heater. The condensation induced saturation changes were confirmed by cores collected from drill-back after the heating phase. The dominant heat transfer mechanism process is by conduction, from comparison of temperature data and TH model results (Tsang and Birkholzer, 1999).

\subsection{Drift Scale Test}

The Drift Scale Test (DST), now in its fifth year, is the largest test in the ESF. The testing methodologies developed in SHT were applied, improved, and expanded in the DST. Nine full-scale heaters are used to simulate waste packages emplaced in a drift. Two panels of wing heaters are used to simulate the thermal environments of multiple drifts. The heating phase is from December 1997 to January 2002, with the temperature at the drift wall reaching $200^{\circ} \mathrm{C}$ (Bodvarsson et al., 2000, Sections 3.10 and 3.12).

Nearly one hundred boreholes were drilled for THCM measurements in the DST (see Figure 12). The ongoing test results indicate that a heat-pipe signature is prominent in temperature measurements. (A heat pipe refers to vapor-liquid counter-flow mechanism and is associated with boiling regions with temperature maintained at nominal boiling point, Pruess et al., 1980a). Early in the test, condensates increased the saturation below the wing heaters. Air-permeability reduction from increased liquid saturation in fractures 
is measured by periodic crosshole air-injection tests, while drying in rock matrix is monitored by geophysical imaging techniques (Birkholzer and Tsang, 2000).

Temperature changes in the rock and observations of dripping from condensation of hot air outside the bulkhead indicate significant redistribution of moisture. Substantial increases of gas-phase $\mathrm{CO}_{2}$ concentration in large regions are measured and simulated well with a thermal-hydrological-chemical (THC) model (Sonnenthal and Spycher, 2001, Section 6.2). The THC model has been used to elucidate the interaction of water with minerals (calcite, silicate, and gypsum), to compare with chemical analyses of liquid samples collected in borehole intervals, to evaluate changes in the chemistry of seepage, and to predict changes in porosity arising from thermally induced precipitation. The projected long-term change in porosity due to heating is small.

\section{Current Focus and Examples of Potential Tests Evolved from Available Results}

Lessons learned from evaluations of underground test results can be used to improve understanding, identify gaps, and provide insights to UZ processes. The current focus of the testing program is on seepage in the lower lithophysal and lower nonlithophysal zones of the TSw, on matrix diffusion and seepage in the drift to drift tests, on potential observation of natural seepage in high percolation areas (behind bulkheads along the Cross Drift or in a crest alcove), and on validation of the active fracture model (Liu et al., 1998) and the flow focusing mechanism (Bodvarsson et al., this issue) through laboratory tests.

Two examples are presented to illustrate the development of different testing concepts. Both examples are related to the diversion of flow: in the drift scale and in faults away from the block. 


\subsection{Drift Shadow Transport}

A drift provides a partial barrier to downward flow of water (percolation or condensate). The presence of a seepage barrier (Section 4.5) indicates that downward water can be diverted by the drift. Directly below the drift will be a shadow of drier rock, as indicated by model results (Birkholzer et al., 1999; Li and Tsang, 2000). If the flux in the drift shadow zone is low enough to make a transition to matrix flow (e.g., Wang and Narasimhan, 1985), flow will be slow, travel times long, and transport of radionuclides reduced (Houseworth et al., 2001). The drift shadow evaluation with testing may confirm or refute these process model predictions.

\subsection{Fault Plan Characterization}

With a substantial fraction of percolation diverted to faults (Section 3.3), fault characterization with liquid water is important to confirm if the flow and transport mechanisms developed with tuff data are applicable to faults. While there are several tests related to faults (Alcove 4 in PTn: Section 5.1, Busted Butte in CHnv: Section 5.2, and Alcove 8 - Niche 3107 in TSw: Section 4.8), the faults tested are local with small displacements $(<1 \mathrm{~m})$. Most of the injection into faults has been through boreholes intercepting the fault at points. There are other large-displacement faults within the potential repository block (e.g., the Sundance fault). Tests in a fault plane, with boreholes drilled along the fault, can be designed with lessons learned from current tests.

\section{Summary and Discussion}

The evolution of geological, hydrological, transport, and thermal tests indicates that a vast amount of knowledge has been gained about UZ processes. The focus shifted 
from intensive surface-based investigations in the early 1980s to underground testing in the late 1990s. Issues continue to arise that change the focus of the UZ testing program.

The issue on the origin of caliches has stimulated extensive geochemical evaluations in the 1980s and ESF investigations in the 1990s. The debate on the benefit of heat continues to have impact on both thermal testing and repository loading designs. Measurements of ${ }^{36} \mathrm{Cl}$ triggered great interests in fast flow paths controlling the early breakthrough at depth.

With the integration of testing and modeling efforts, important factors are identified for natural attributes of Yucca Mountain: (1) limited water contact with waste packages, and (2) reduction in radionuclide concentration during transport. The percolation estimates have led to the comprehensive evaluation of borehole and ESF data. The seepage tests in welded tuff were initiated with observations of a dry ESF, and address the first attribute. The tracer tests in all units address different aspects of the second attribute.

The main focus of current underground testing activities is on the UZ processes that control seepage into drifts, heat transfer around drifts, and transport through the UZ. Underground studies have evolved through stages as they develop new emphases and different approaches. In the mid-1990s, methodologies developed and deployed in surface-based borehole testing were applied to most of the alcoves. Four North Ramp and two Ghost Dance fault alcoves were predominantly used as drill bays for horizontal and slanted boreholes to collect cores, measure air permeability, and sample gases.

Recognizing the need to address directly the water issue, a different set of tests have evolved that use water and aqueous phase tracers to directly evaluate flow and 
transport processes. In addition to niches, Alcove 8, and systematic testing in the Cross Drift, Alcoves 1, 4, and 6 were adopted for liquid tests at different scales for seepage, fracture-matrix interaction, and matrix diffusion processes. The Busted Butte facility was excavated for transport tests. Water has also been mobilized by heating and vaporization in the single heater and drift scale thermal tests at Alcove 5.

Field tests provide realistic data to calibrate UZ models. In the absence of realistic data and calibrated models, performance assessment models tend to use conservative estimates with large uncertainties. The current focus of the testing program and two examples are presented (drift shadow zone and faults within the potential repository block, Section 7) to capture the essence of progression for tests to improve process understanding, remove conservative estimates, and enhance realistic representation of UZ processes at Yucca Mountain.

\section{References}

Ahlers, C.F., Finsterle, S., and Bodvarsson, G.S., 1999. "Characterization and Prediction of Subsurface Pneumatic Response at Yucca Mountain, Nevada." Journal of Contaminant Hydrology, 38, (1-3), 47-68.

Birkholzer, J.T., and Tsang, Y.W., 2000. "Modeling the Thermal-Hydrologic Processes in a Large-Sclae Underground Heater Test in Partially Saturated Fractured Tuff." Water Resources Research, 36, (6), 1431-1447.

BIRKHOLZER, J., LI, G., TSANG, C.-F., AND TSANG, Y., 1999. "MODELING STUDIES AND ANALYSIS OF SEEPAGE INTO DRIFTS AT YUCCA MOUNTAIN." JOURNAL OF CONTAMINANT HYDROLOGY, 38, (1-3), 349-384. 
BODVARSSON, G.S., WU, Y.-S., AND ZHANG, K., THIS ISSUE. "DEVELOPMENT OF DISCRETE FLOW PATHS IN UNSATURATED FRACTURES AT YUCCA MOUNTAIN." JOURNAL OF CONTAMINANT HYDROLOGY.

Bodvarsson, G.S., Ahlers, C.F., Cushey, M., Dove, F.H., Finsterle, S.A., Haukwa, C.B., Hinds, J., Ho, C.K., Houseworth, J., Hu, Q., Liu, H.H., Pendleton, M., Sonnenthal, E.L., Unger, A.J., Wang, J.S.Y., Wilson, M., and Wu, Y.-S., 2000. "Unsaturated Zone Flow and Transport Model Process Model Report." TDR-NBS-HS-000002 REV00. Civilian Radioactive Waste Management System Management \& Operating Contractor (CRWMS M\&O), Las Vegas, NV.

Buesch, D.C., and Spengler, R.W., 1998. "Character of the Middle Nonlithophysal Zone of the Topopah Spring Tuff at Yucca Mountain." High-Level Radioactive Waste Management, Proceedings of the Eighth International Conference, Las Vegas, Nevada, May 11-14, 1998. pp. 16-23.

Buscheck, T.A., and Nitao, J.J. 1993. "Repository-Heat-Driven Hydrothermal Flow at Yucca Mountain, Part I: Modeling and Analysis." Nuclear Technology, 104, (3), 418-448.

Conca, J., ed., 2000. Unsaturated Zone and Saturated Zone Transport Properties. CRWMS M\&O 2000 (U0100), ANL-NBS-HS-000019 REV 00. CRWMS M\&O, Las Vegas, NV.

Cook, P., 2000. "In-Situ Pneumatic Testing at Yucca Mountain." International Journal of Rock Mechanics and Mining Sciences, 37, (1-2), 357-367. 
Day, W.C., Potter, C.J., Sweetkind, D.S., Dickerson, R.P., and San Juan, C.A., 1998. Bedrock Geologic Map of the Central Block Area, Yucca Mountain, Nye County, Nevada. Map I-2601. U.S. Geological Survey, Washington, D.C.

DOE (U.S. Department of Energy), 1988. Site Characterization Plan Yucca Mountain Site, Nevada Research and Development Area, Nevada. DOE/RW-0199. Nine volumes. U.S. Department of Energy, Office of Civilian Radioactive Waste Management. Washington, D.C.

Fabryka-Martin, J.T., ed., 2000. Analysis of Geochemical Data for the Unsaturated Zone. ANL-NBS-HS-000017 REV 00. CRWMS M\&O, Las Vegas, NV.

Faybishenko, B., Bodvarsson, G.S., and Salve, R., this issue. "On the Physics of Unstable Infiltration, Seepage, and Gravity Drainage in Partially Saturated Fractured Tuff." Journal of Contaminant Hydrology.

Finsterle, S., Ahlers, C.F., and Trautz, R.C, this issue. "Inverse and Predictive Modeling of Seepage into Underground Openings." Journal of Contaminant Hydrology.

Flint, L.E., 1998. Characterization of Hydrogeologic Units Using Matrix Properties, Yucca Mountain, Nevada. Water-Resources Investigations Report 97-4243. U.S. Geological Survey, Denver, CO.

Flint, L.E., and Flint, A.L., 1995. Shallow Infiltration Processes at Yucca Mountain, Nevada-Neutron Logging Data 1984-93. Water-Resources Investigations Report 95-4035. U.S. Geological Survey, Denver, CO. 
Forester, R.M., 2000. Future Climate Analysis. USGS, 2000 (U0005). ANL-NBS-GS000008 REV 00. U.S. Geological Survey, Denver, CO.

Hevesi, J.A., Ambos, D.S., and Flint, A.L., 1994. "A Preliminary Characterization of the Spatial Variability of Precipitation at Yucca Mountain, Nevada." High-Level Radioactive Waste Management, Proceedings of the Fifth Annual International Conference, Las Vegas, Nevada, May 22-26, 1994. 4, pp. 2520-2529.

Houseworth, J., Moridis, G., and Bodvarsson, G.S., 2001. "The Effects of Drift Shadow on Radionuclide Transport." High-Level Radioactive Waste Management, Proceedings of the Ninth Annual International Conference, Las Vegas, Nevada, April 29-May 3, 2001.

Hu, Q., Salve, R., Springfellow, W.T., and Wang, J.S.Y., 2001. Field tracer-transport tests in unsaturated fractured tuff. Journal of Contaminant Hydrology, 51, 1-12.

LeCain, G.D., 1997. Air-Injection Testing in Vertical Boreholes in Welded and Nonwelded Tuff, Yucca Mountain, Nevada. Water-Resources Investigations Report 96-4262. U.S. Geological Survey, Denver, CO.

Li, G., and Tsang, C.F., 2000. Seepage Model for PA Including Drift Collapse. CRWMS M\&O 2000 (U0075). MDL-NBS-HS-000002 REV 01, CRWMS M\&O, Las Vegas, NV.

Liu, H.H., Doughty, C., and Bodvarsson, G.S. 1998. "An Active Fracture Model for Unsaturated Flow and Transport in Fractured Rocks." Water Resources Research, 34, (10), 2633-2646. 
Liu, H.H., Haukwa, C.B., Ahlers, C.F., Bodvarsson, G.S., Flint, A.L., and Guertal, W.B., this issue. "Modeling Flow and Transport in Unsaturated Fractured Rock: an Evaluation of the Continuum Approach." Journal of Contaminant Hydrology.

Majer, E.L., Gritto, R., Daley, T.M., Korneev, V.A., Feigher, M.A., and Peterson, J.E., 1998. Full Scale Tomographic Seismic Imaging of the Potential Repository Horizon. SP3B2FM4. \#BA0000000-01717-5700-00019. CRWMS M\&O, Las Vegas, NV.

Montazer, P., 1987. "Monitoring Hydrologic Conditions in the Vadose Zone in Fractured Rocks, Yucca Mountain, Nevada." Flow and Transport through Unsaturated Fractured Rock. Evans, D.D. and Nicholson, T.J., eds. Geophysical Monograph No. 42, 31-42. American Geophysical Union, Washington, D.C.

Montazer, P. and Wilson, W.E. 1984. Conceptual Hydrologic Model of Flow in the Unsaturated Zone, Yucca Mountain, Nevada. Water-Resources Investigations Report 84-4345. USGS, Lakewood, CO.

Paces, J.B.; Newmark, L.A.; Marshall, B.D.; Whelan, J.F.; and Peterman, Z.E., 1998. "Inferences for Yucca Mountain Unsaturated-Zone Hydrology from Secondary Minerals." High-Level Radioactive Waste Management, Proceedings of the Eighth International Conference, Las Vegas, Nevada, May 11-14, 1998. pp. 36-39.

Philip, J.R.; Knight, J.H.; and Waechter, R.T. 1989. "Unsaturated Seepage and Subterranean Holes: Conspectus, and Exclusion Problem for Circular Cylindrical Cavities." Water Resources Research, 25, (1), 16-28. 
Pruess, K.; Wang, J.S.Y.; and Tsang, Y.W., 1990a. "On Thermohydrologic Conditions Near High-Level Nuclear Wastes Emplaced in Partially Saturated Fractured Tuff: 1. Simulation Studies with Explicit Consideration of Fracture Effects." Water Resources Research, 26, (6), 1235-1248.

Pruess, K.; Wang, J.S.Y.; and Tsang, Y.W., 1990b. "On Thermohydrologic Conditions Near High-Level Nuclear Wastes Emplaced in Partially Saturated Fractured Tuff: 2. Effective Continuum Approximation." Water Resources Research, 26, (6), 1249-1261.

Rousseau, J.P.; Kwicklis, E.M.; and Gillies, D.C., 1999. Hydrogeology of the Unsaturated Zone, North Ramp Area of the Exploratory Studies Facility, Yucca Mountain, Nevada. Water-Resources Investigations Report 98-4050. U.S. Geological Survey, Denver, CO.

Salve, R., and Olendburg, C.M., 2001. "Water Flow in a Fault in Altered Nonwelded Tuff." Water Resources Research, 37, (12), 3043-3056.

Salve, R., Wang, J.S.Y. and Doughty, C., 2002. "Liquid Flow in Unsaturated Fractured Welded Tuffs: I. Field Investigations." Journal of Hydrology, 256, 60-79.

Scott, R.B. and Bonk, J., 1984. Preliminary Geologic Map of Yucca Mountain, Nye County, Nevada, with Geologic Sections. Open-File Report 84-494. U.S. Geological Survey, Denver, CO. 
Sonnenthal, E., and Spycher, N., 2001. Drift-Scale Coupled Processes (DST and THC Seepage) Models. MDL-NBS-HS-000001 REV 01. CRWMS M\&O, Las Vegas, NV.

Stuckless, J.S.; Peterman, Z.E.; and Muhs, D.R., 1991. "U and Sr Isotopes in Ground Water and Calcite, Yucca Mountain, Nevada: Evidence Against Upwelling Water." Science, 254, 551-554.

TRAUTZ, R.C. AND WANG, J.S.Y., 2001. "EVALUATION OF SEEPAGE INTO AN UNDERGROUND OPENING USING SMALL-SCALE FIELD EXPERIMENTS, YUCCA MOUNTAIN, NEVADA." MINING ENGINEERING, 53, (12), 41-44.

Tsang, Y.W. and Birkholzer, J.T., 1999. "Predictions and Observations of the ThermalHydrological Conditions in the Single Heater Test." Journal of Contaminant Hydrology, 38, (1-3), 385-425.

Tseng, P.H., Soll, W.E., Gable, C.W., Turin, H.J., and Bussod, G.Y., this issue. "Modeling Flow and Transport at the Busted Butte Field Test Site." Journal of Contaminant Hydrology.

Wang, J.S.Y. and Elsworth, D., 1999. "Permeability Changes Induced by Excavation in Fractured Tuff." Rock Mechanics for Industry, Proceedings of the 37th U.S. Rock Mechanics Symposium, Vail, Colorado, June 6-9, 1999. Amadei, B., ed. 2, 751757. A.A. Balkema. Rotterdam, The Netherlands.

Wang, J.S.Y. and Narasimhan, T.N., 1985. "Hydrologic Mechanisms Governing Fluid Flow in a Partially Saturated, Fractured, Porous Medium." Water Resources Research, 21, (12), 1861-1874. 
Wang, J.S.Y.; Trautz, R.C.; Cook, P.J.; Finsterle, S.; James, A.L.; and Birkholzer, J., 1999. "Field Tests and Model Analyses of Seepage into Drift." Journal of Contaminant Hydrology, 38, (1-3), 323-347.

Weeks, E.P., 1987. "Effect of Topography on Gas Flow in Unsaturated Fractured Rock: Concepts and Observations." Flow and Transport Through Unsaturated Fractured Rock. Evans, D.D. and Nicholson, T.J., eds. Geophysical Monograph 42, 165170. American Geophysical Union, Washington, D.C.

Winograd, I.J., 1981. "Radioactive Waste Disposal in Thick Unsaturated Zones." Science, 212, (4502), 1457-1464.

Wu, Y-S.; Haukwa, C.; and Bodvarsson, G.S., 1999. "A Site-Scale Model for Fluid and Heat Flow in the Unsaturated Zone of Yucca Mountain, Nevada." Journal of Contaminant Hydrology, 38, (1-3), 185-215.

\section{Figure Captions}

Fig. 1. Schematic illustration of the main surface-based deep boreholes and underground drifts, and the major faults in the vicinity of Yucca Mountain.

Fig. 2. Chronology of the unsaturated zone site characterization program at Yucca Mountain.

Fig. 3. Geological and geophysical studies on the surface and along the ESF (tomographic seismic imaging from Majer et al., 1998).

Fig. 4. Damp feature observed during dry excavation of Niche 3566 and bomb-pulse ${ }^{36} \mathrm{Cl} / \mathrm{Cl}$ signals along the ESF (Wang et al., 1999; Fabryka-Martin, 2000).

Fig. 5. Lower lithophysal seepage test at Cross Drift Niche 1620 (R.C. Trantz and P.J. Cook, personal communications). 
Fig. 6. Drift seepage tests at Niche 3650 (Wang et al., 1999; Trantz and Wang, 2001).

Fig. 7. Fracture-matrix interaction test at Alcove 6 (Salve et al., 2002).

Fig. 8. El Niño infiltration and seepage test at Alcove 1 (Liu et al., this issue).

Fig. 9. Paintbrush fault and porous matrix test at Alcove 4 (Salve and Odenburg, 2001).

Fig. 10. Unsaturated zone transport test at Busted Butte (Conca, 2000; Tseng et al., this issue).

Fig. 11. Single heater test at Alcove 5 (Tsang and Birkholzer, 1999).

Fig. 12. Drift scale test at Alcove 5 (Birkholzer and Tsang, 2000). 


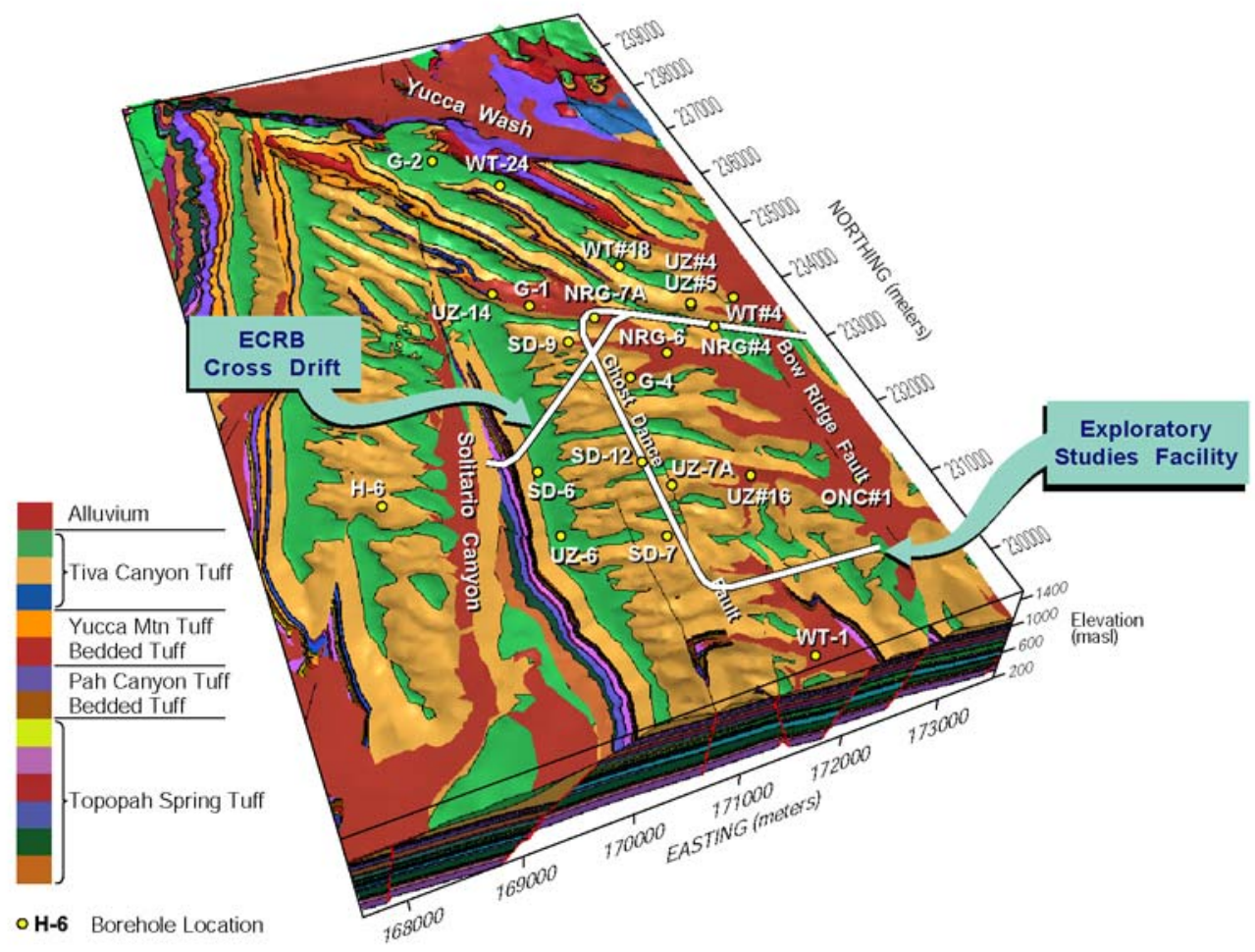

Figure 1. Schematic illustration of the main surface-based deep boreholes and underground drifts, and the major faults in the vicinity of Yucca Mountain. 


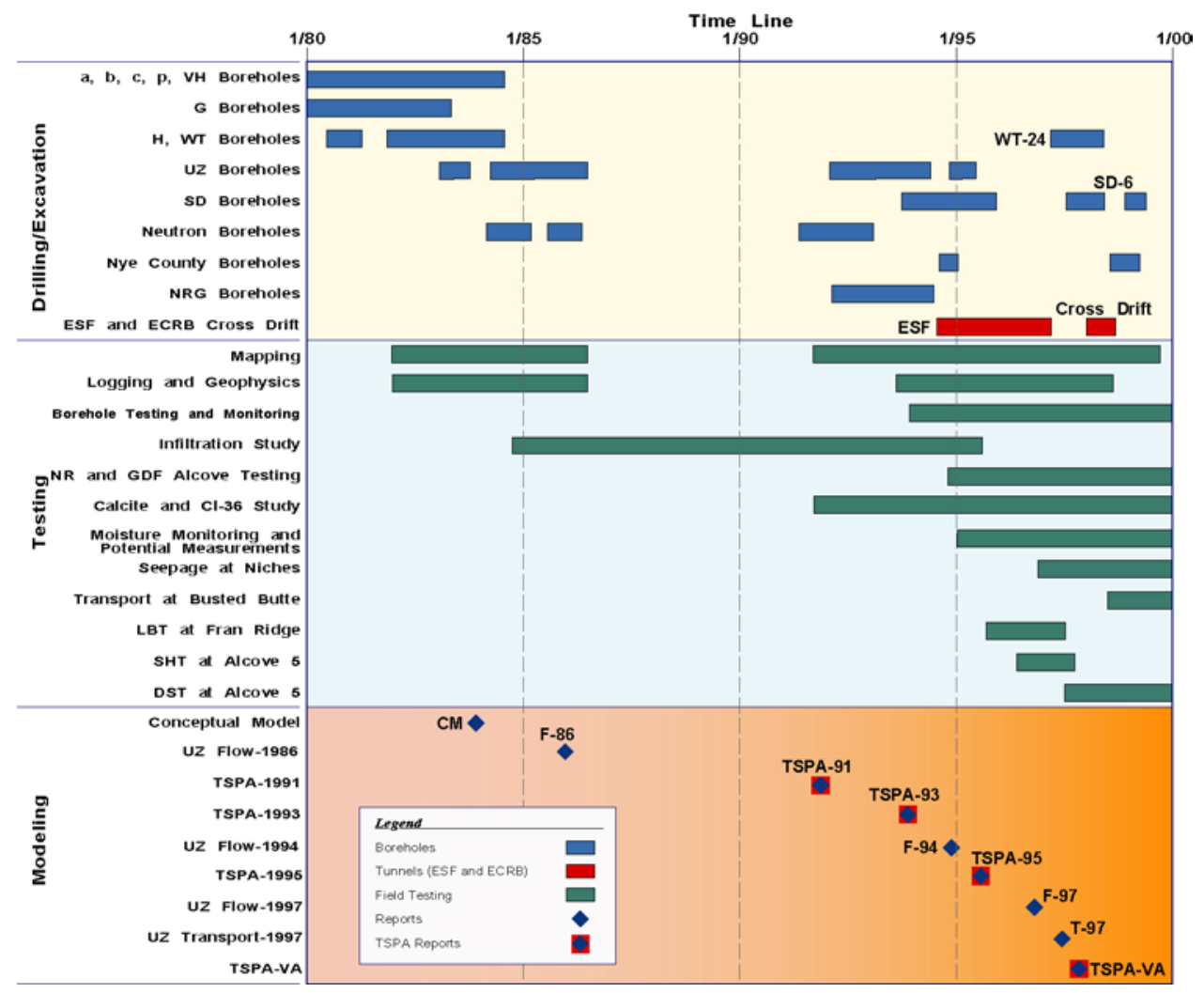

Figure 2. Chronology of the unsaturated zone site characterization program at Yucca Mountain. 


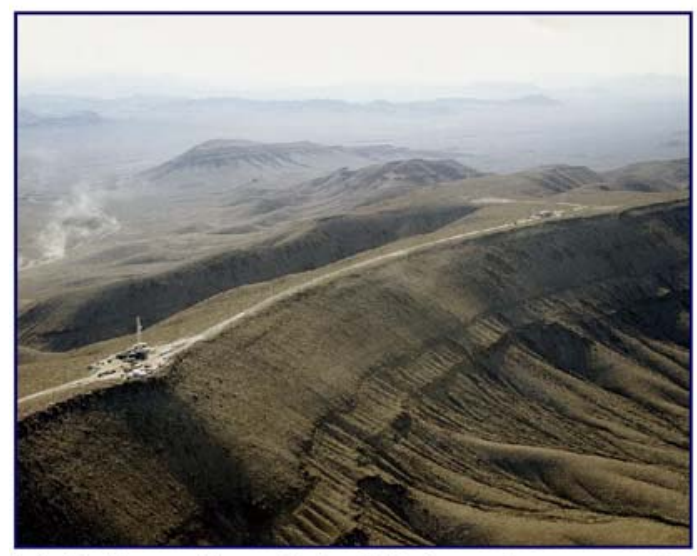

(a) Drilling of borehole SD-6 on the crest of Yucca Mountain

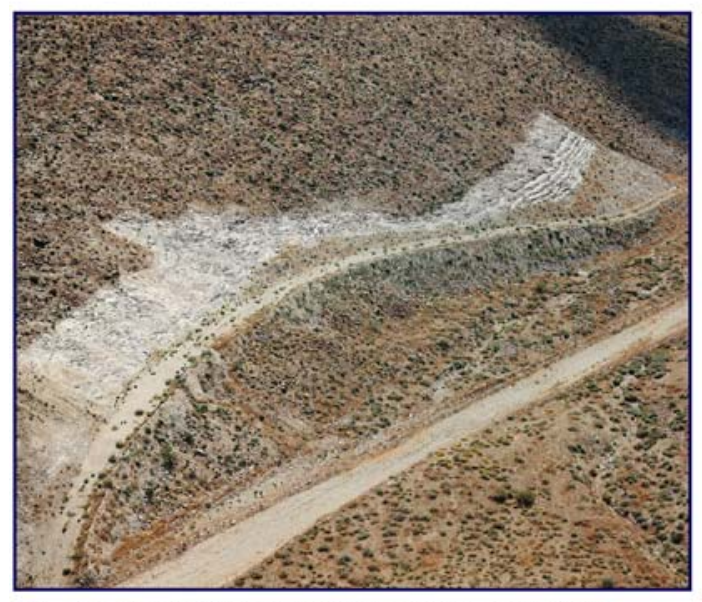

(b) Pavement cleared for fault mapping

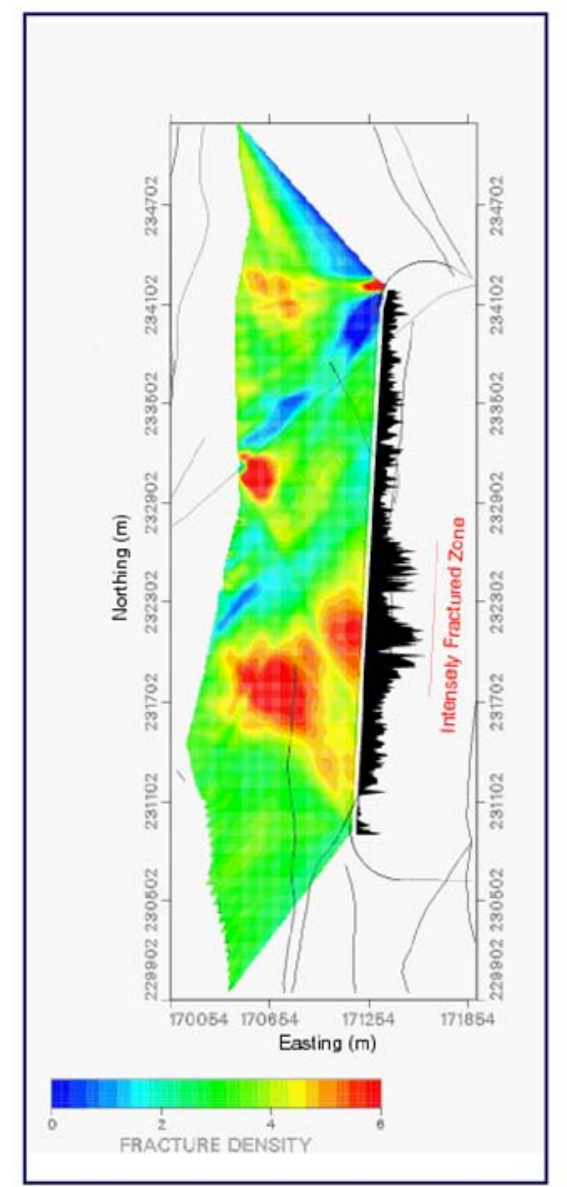

(c) Fracture density distributions by detailed line survey and seismic tomograph

Figure 3. Geological and geophysical studies on the surface and along the ESF (tomographic seismic imaging from Majer et al., 1998). 


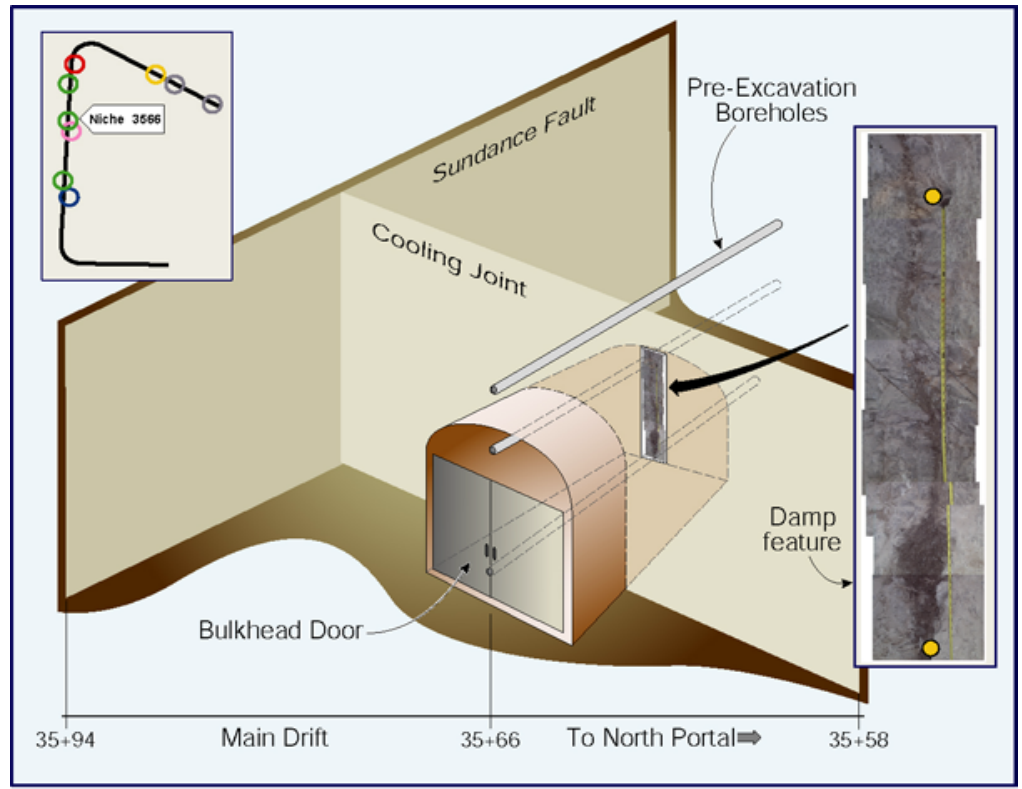

(a) Schematic of sealed Niche 3566 in the ESF

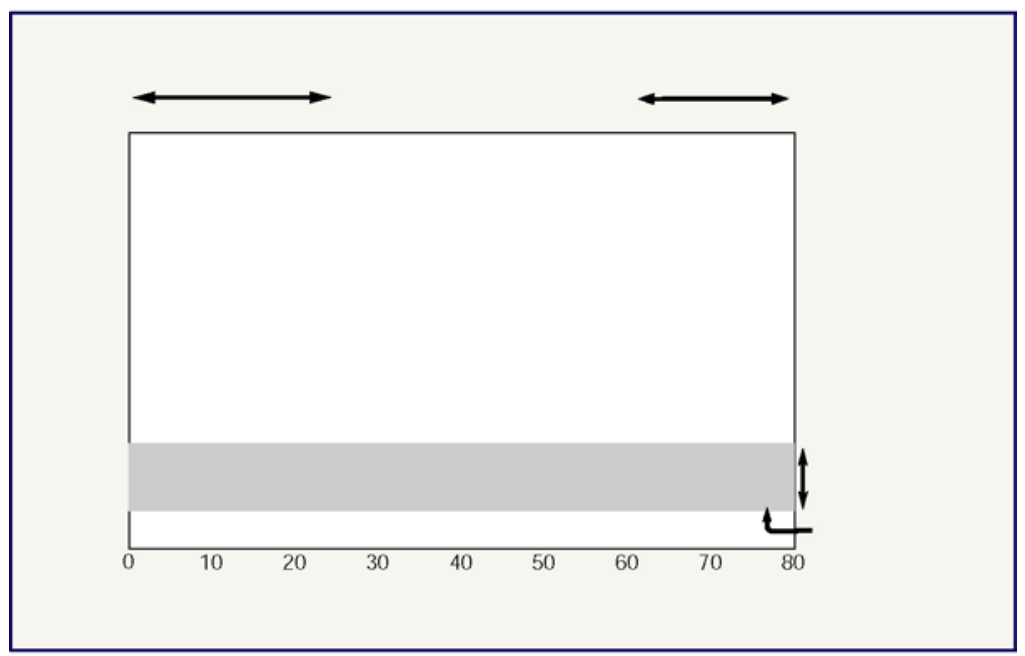

(b) Distribution of ${ }^{36} \mathrm{Cl} / \mathrm{Cl}$ in the $\mathrm{ESF}$

Figure 4. Damp feature observed during dry excavation of Niche 3566 and bomb-pulse ${ }^{36} \mathrm{Cl} / \mathrm{Cl}$ signals along the ESF (Wang et al., 1999; Fabryka-Martin, 2000). 


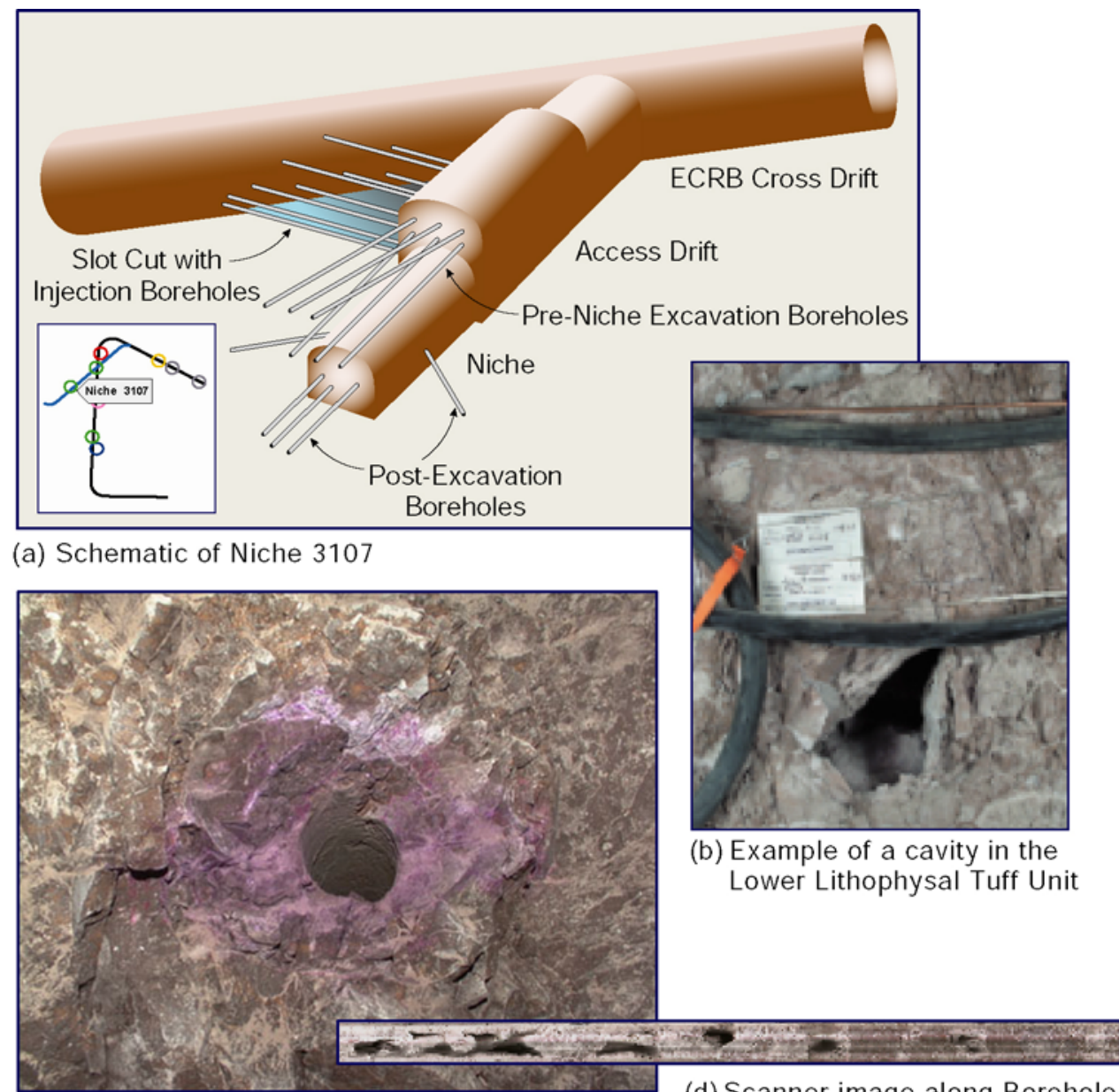

(c) Example of a rhodamine plume from

(d) Scanner image along Borehole liquid release AK-1 at Niche1620

Figure 5. Lower lithophysal seepage test at Cross Drift Niche 1620 (R.C. Trantz and P.J. Cook, personal communications). 


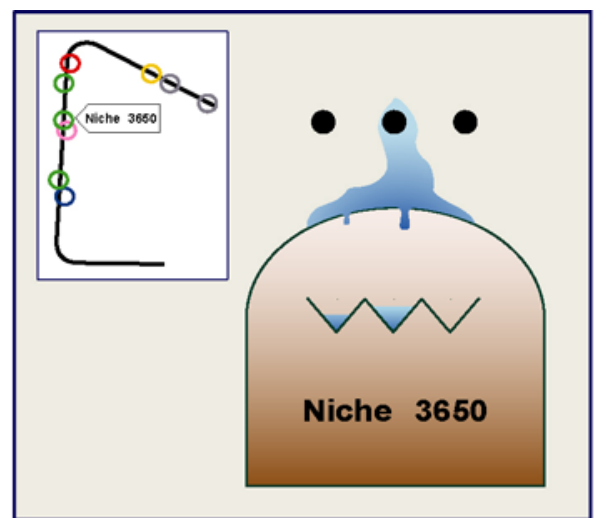

(a) Schematic of Niche 3650 in the ESF

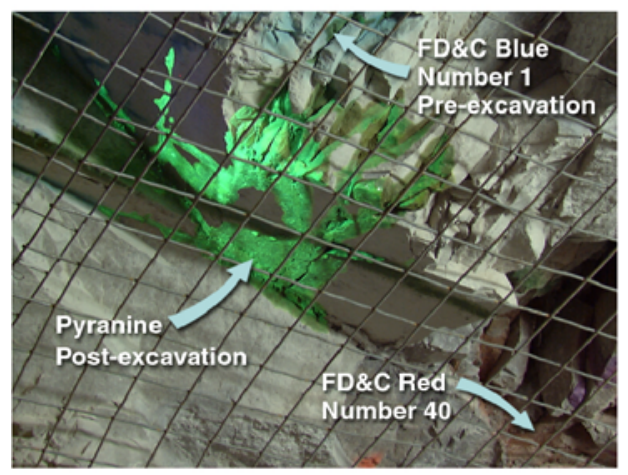

(c) Flow paths indicated by dye tracers on niche ceiling

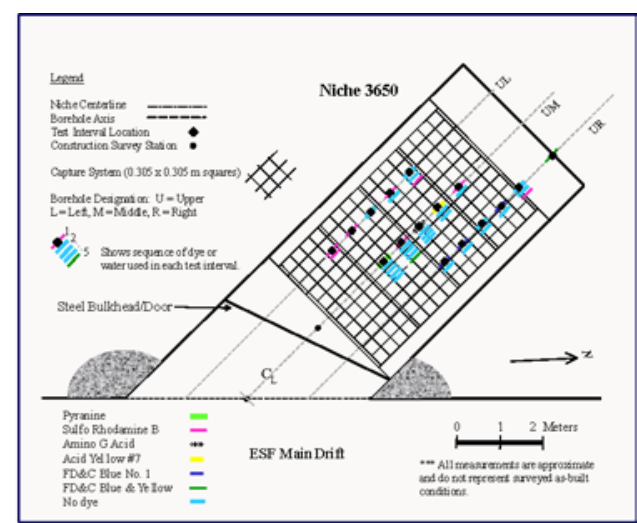

(b) Seepage capture system

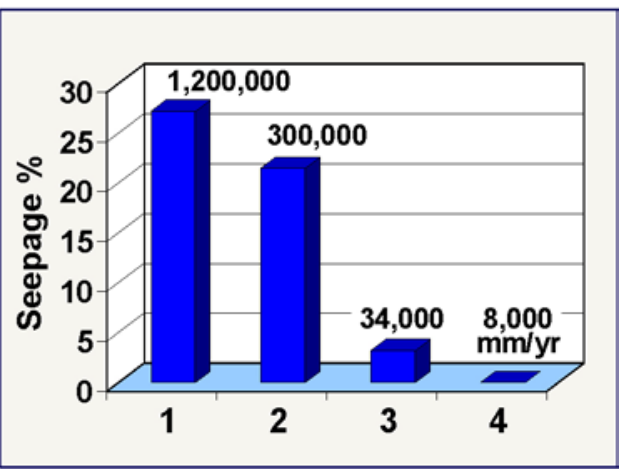

(d) Example sequence of liquid release tests to determine seepage thresholds

Figure 6. Drift seepage tests at Niche 3650 (Wang et al., 1999; Trantz and Wang, 2001). 

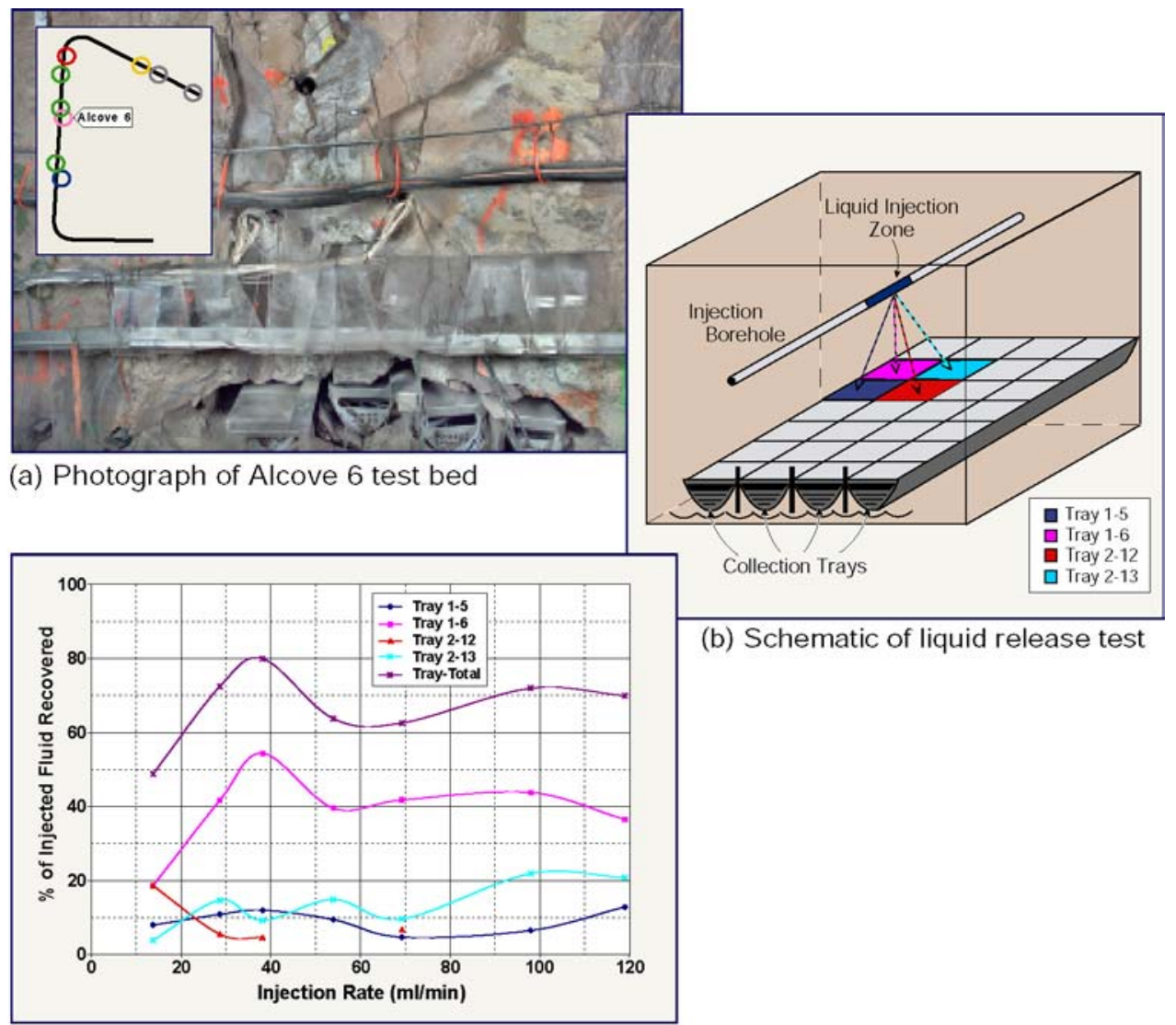

(b) Schematic of liquid release test

(c) Water collected in the slot

Figure 7. Fracture-matrix interaction test at Alcove 6 (Salve et al., 2002). 


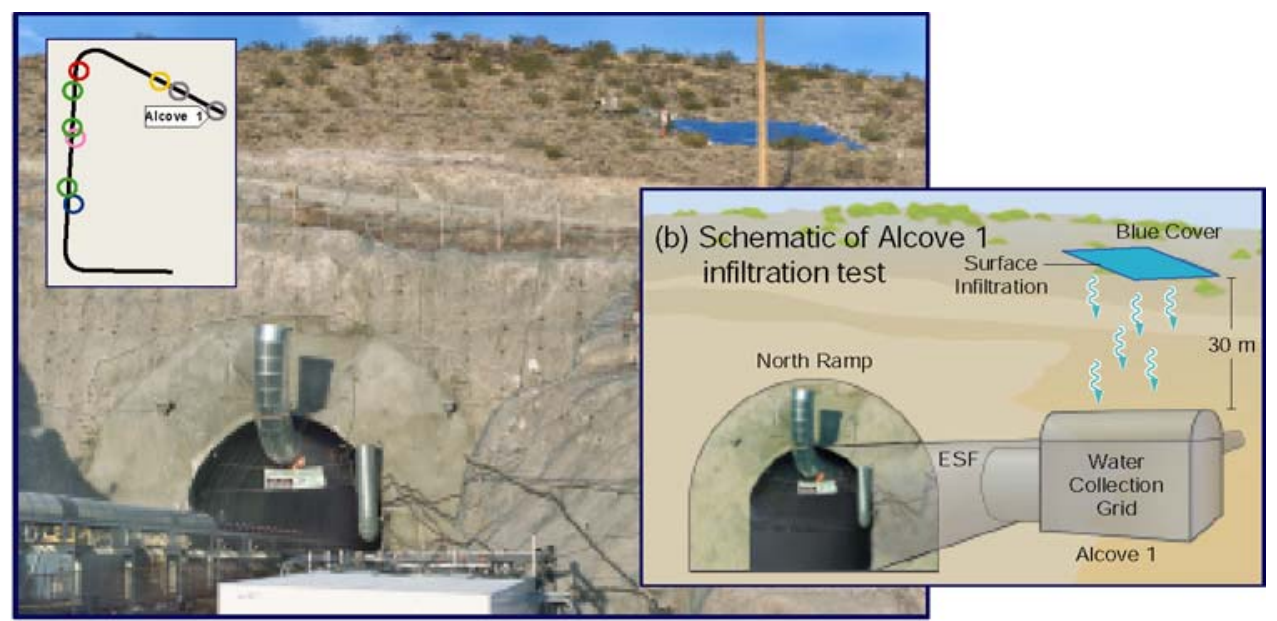

(a) Photography of ESF North Portal and infiltration plot (blue cover)

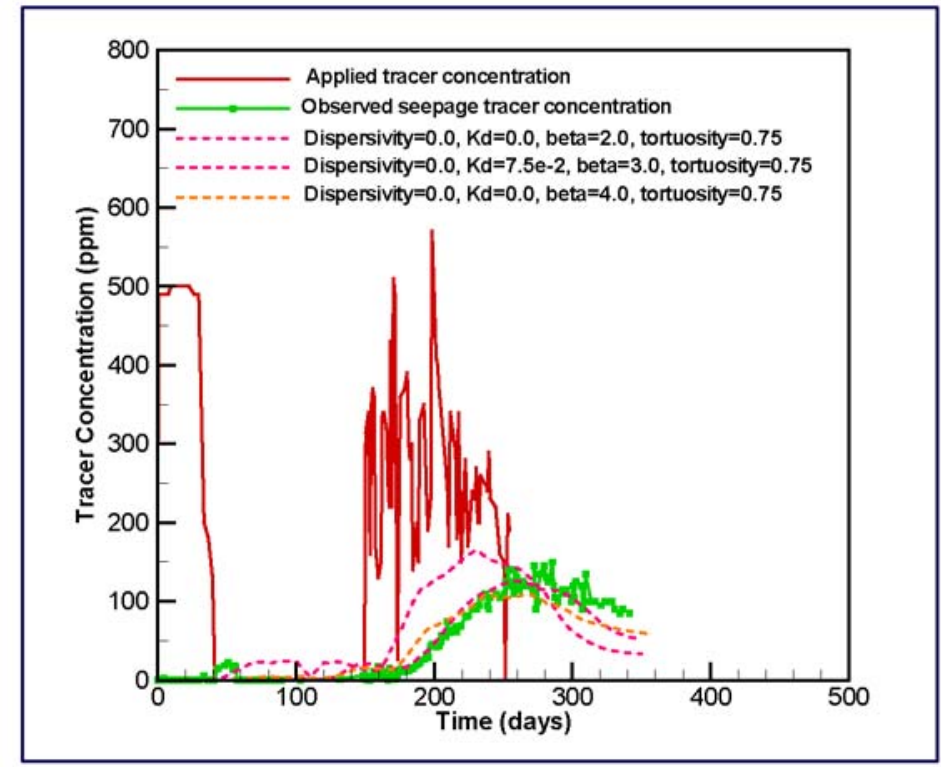

(c) Tracer breakthoughs test results and model predictions with matrix diffusion

Figure 8. El Niño infiltration and seepage test at Alcove 1 (Liu et al., this issue). 


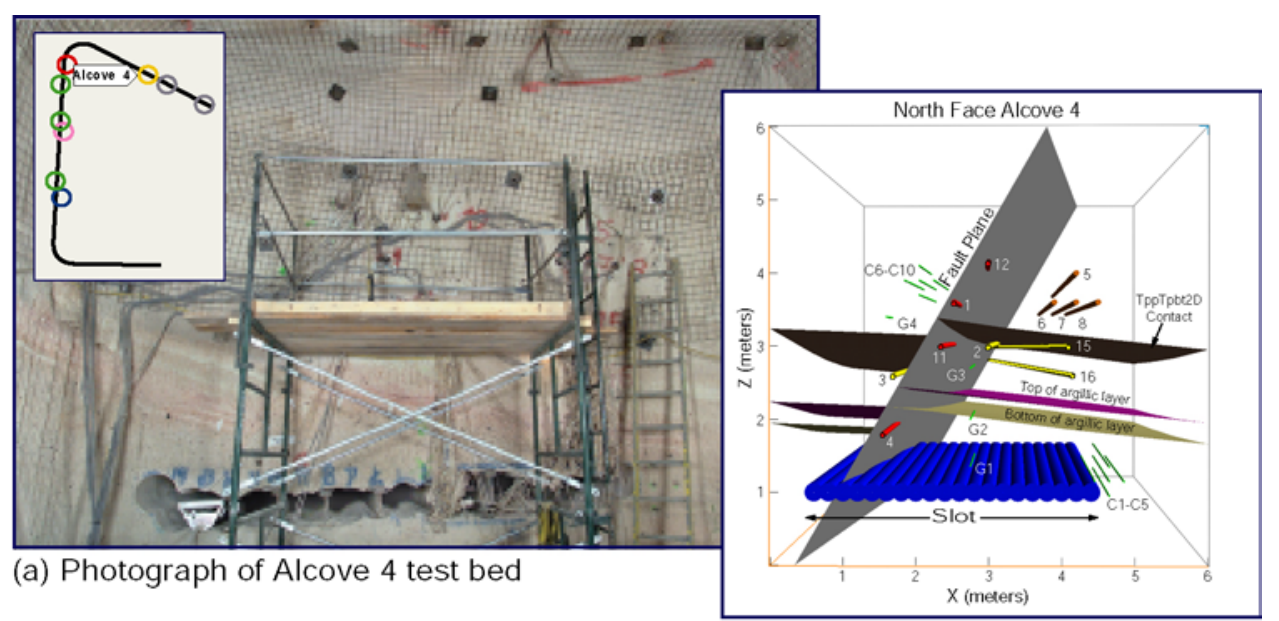

(b) Schematic of boreholes at Alcove 4

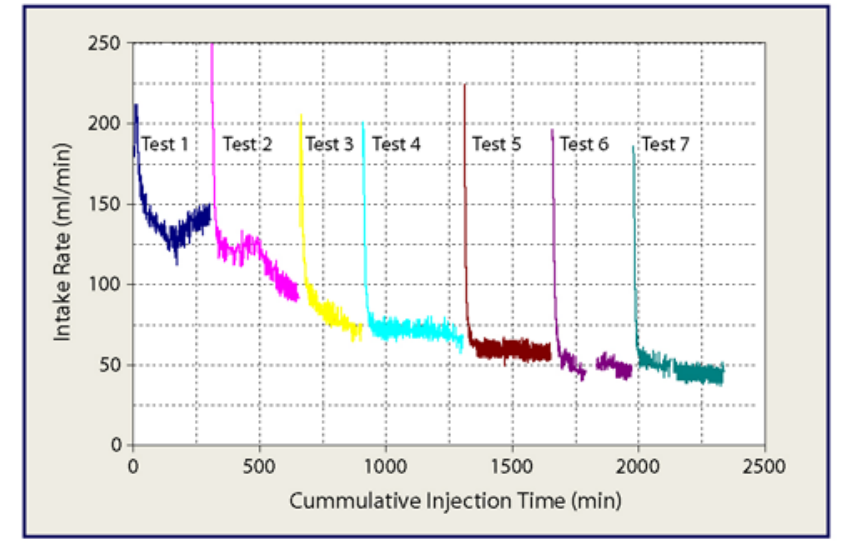

(c) Water intake rate at a PTn fault

Figure 9. Paintbrush fault and porous matrix test at Alcove 4 (Salve and Odenburg, 2001). 


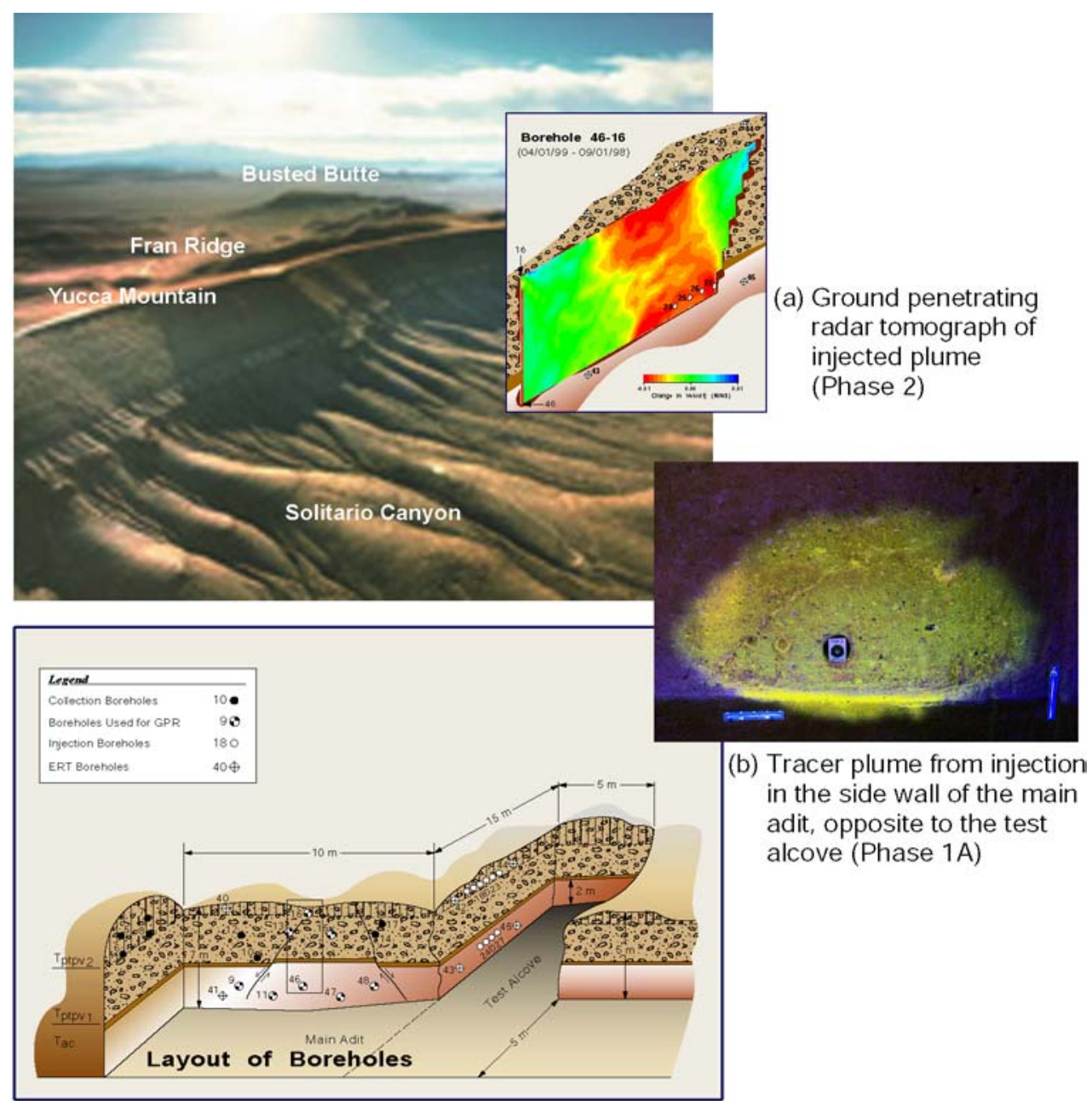

(c) Schematic of Busted Butte test area

Figure 10. Unsaturated zone transport test at Busted Butte (Conca, 2000; Tseng et al., this issue). 

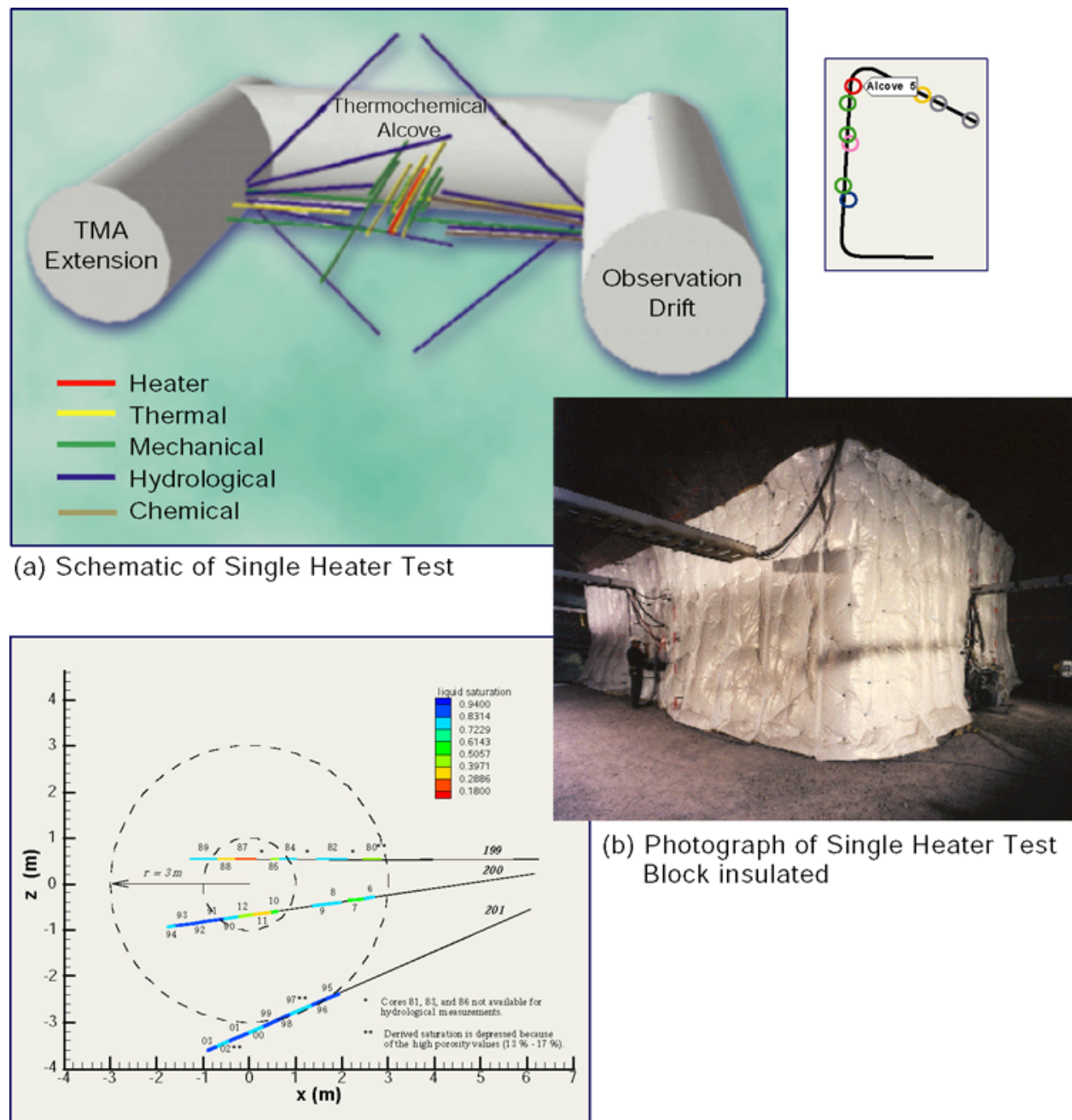

(b) Photograph of Single Heater Test Block insulated

(c) Distributed liquid saturation in cores after cooling phase

Figure 11. Single heater test at Alcove 5 (Tsang and Birkholzer, 1999). 

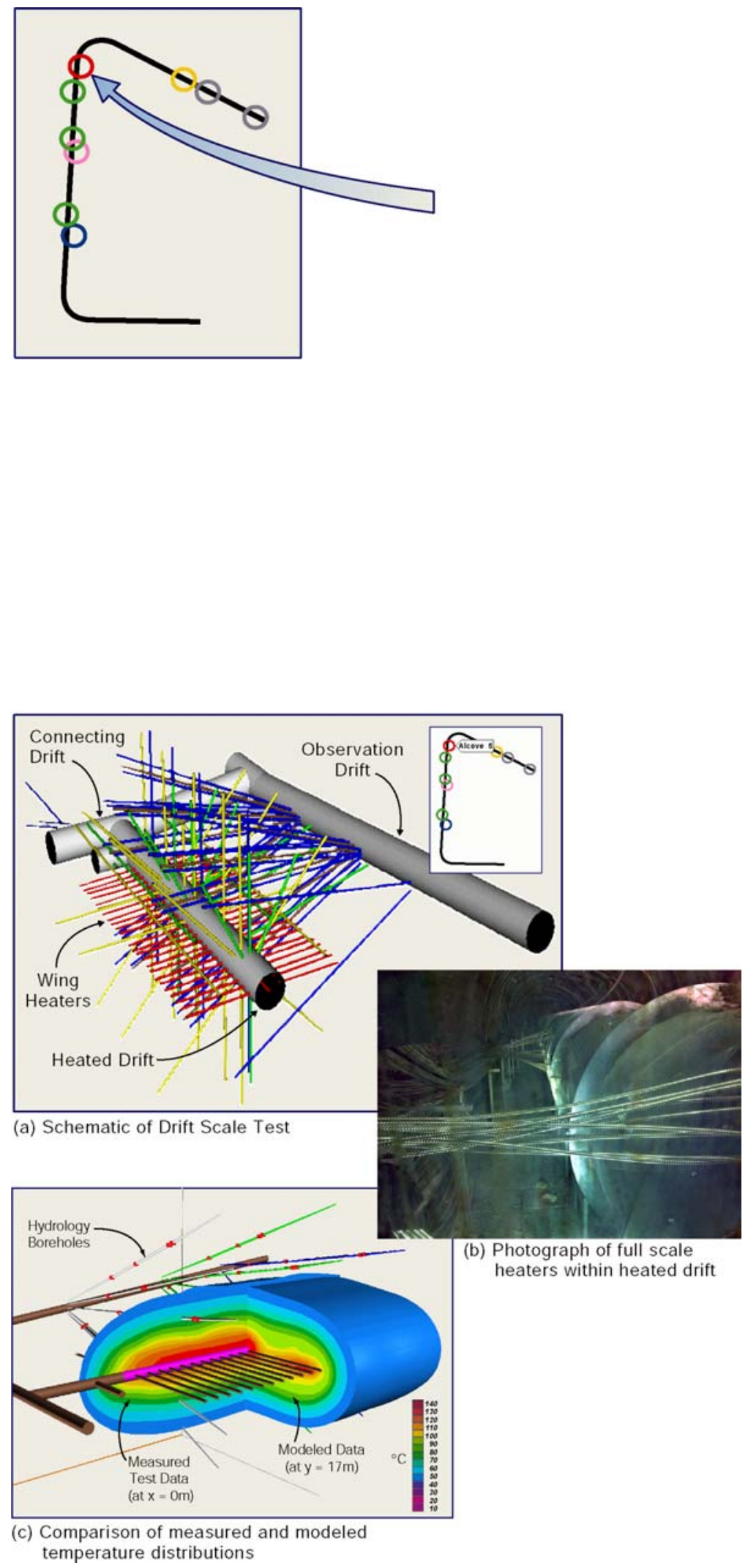

Figure 12. Drift scale test at Alcove 5 (Birkholzer and Tsang, 2000). 
